Volume 6 Issue 4, December 2019

Nationally Accredited Journal,

Decree No. B/4130/E5/E5.2.1/2019

\title{
Review Of Juridical Registration Implementation And Transfer Of Land Or Building With Deed Land Sale In The Office Of The Samarinda City
}

\begin{abstract}
Winarti $^{1}$, Rofi'atun ${ }^{2}$ and Ngadino $^{3}$
Abstract. The purpose of this study was to: 1) analyze the implementation of transitional registration of rights to land and or building with the Sale and Purchase Agreements in the Land Office Samarinda. 2) Analyze the obstacles in the implementation of transitional registration of rights to land and or building with the Sale and Purchase Agreements in the Land Office Samarinda. 3) Know and analyze the solutions to overcome obstacles in the implementation of transitional registration of rights to land and or building with the Sale and Purchase Agreements in the Land Office Samarinda

This research is normative juridical approach, with specification of descriptive analysis. The collection of primary and secondary data obtained by interview and literature.

The research results are: 1 ) Each transition of ownership of the land by way of sale and purchase, subsequent to the transfer of rights by PPAT local as evidenced by the deed of sale, then PPAT concerned within 7 business days from the signing of the deed shall register the transfer of property rights on the ground at the local land Office Samarinda especially by bringing in heaps of applicants required. 2) Barriers that occurs in the transition process of land rights through sale and purchase of the Land Office of Samarinda is because people are reluctant to take care of their land rights switchover due to their cost, according them high enough and only seize their working time. The Land Office step in overcoming these obstacles, Keywords: Sale and Purchase Agreements; Registration of Land; Certificate.
\end{abstract}

\section{Introduction}

Soil is the potential of the country that was instrumental in supporting development. Tenure is essentially a reflection of mankind's view of himself as a man in relation to the ground. Man's relationship with the land raises the authority and responsibility for the welfare of yourself and others. The use of the function of the earth and water, as well as the natural riches contained therein is aimed to achieve the greatest prosperity of all the people of Indonesia. As in article 33, paragraph 3 of the 1945 Constitution which reads that the land and water and natural resources contained in it are controlled by the state and used for the greatest prosperity of the people. ${ }^{4}$

The rapid increase in demand for land with the limited supply of land at this time, also have a major impact for the increase in value and the price of land. This increases the potential for conflicts and problems related to or caused by the soil. The increasing complexity of the problems of human life caused by the current land requires that

\footnotetext{
1 Student of Master of Notary Program, Universitas Islam Sultan Agung Email: windyw866@gmail.com

2 Student of Master of Law, Unissula, Universitas Islam Sultan Agung email rofiatun.sh@gmail.com

${ }_{3}^{3}$ Public Notary / Land Acquisition Officer at Semarang City

${ }^{4}$ Law of the Republic of Indonesia Number 5 of 1960 concerning provisions Agrarian
} 
there is a rule governing the legal guarantee in the relationship between man and land. ${ }^{5}$

As a concrete manifestation of Article 33 paragraph (3) of the Constitution of the State of the Republic of Indonesia in 1945, it gives birth to Law No. 5 of 1960 on Basic Regulation of Agrarian better known as the Basic Agrarian Law. In Article 2 (1) of the Basic Agrarian Law is stated that: "The earth, water and air space including the natural resources therein at its highest level controlled by the State as an organization of power the whole people" Through the controlling right of the State it is the State as ruling body will be able to continue to control or direct the management function of the earth, water and air space and the natural riches contained therein in accordance with existing regulations and policies, namely within the scope of judicial control of the public. $^{6}$

One of the legal acts in the transfer of tenure rights to land and or building is most often done by the public is through buying and selling. Article 1457 Book of the Law of Civil Law (Civil Code) states buying and selling is an agreement, whereby one party to bind himself to submit a material and the other party to pay the price that has been promised. The seller is obliged to hand over the goods sold, while the buyer is obliged to pay the price of the purchased goods to the seller. ${ }^{7}$

In article 19 of Government Regulation No. 10 of 1961 that land purchase must be evidenced by a deed drawn up before the Land Deed Official (PPAT). So purchase rights over the land and or building should be carried out in the presence of PPAT. It thus as evidence that there has been buying and selling rights over the land and then PPAT make the deed of sale. ${ }^{8}$ PPAT Deed is made by PPAT deed as evidence has implemented certain deeds over land rights or property of the Upper Unit Flats. ${ }^{9}$

Before the deed of sale made PPAT, it is required for the parties to submit the necessary paperwork to PPAT, namely:

- If the soil is certified: the original land certificate and proof of payment of registration fee.

- If the soil has not been certified: certificate that the land is not yet certified, the land papers that need reinforcement by the village chief and district head. Equipped with the letters that prove the identity of the seller and buyer are required for certification of the land after the completion of the sale and purchase.

Once the deed is made, no later than 7 working days after the deed was signed, PPAT hand over the deed to the Land Office for the registration of the transfer of rights. ${ }^{10}$

Samarinda is the capital city located in the province of East Kalimantan. Samarinda city is a city that developed because a lot of development. Many development makes a lot of demand for land. Land and or buildings owned by the public largely owned land purchase.Based on the background of the above problems, the authors are interested to analyze the problems with the title"Implementation of the Judicial Review

\footnotetext{
${ }^{5}$ Dyara Radhite Oryza Fea, 2018, Panduan Mengurus Tanah Rumah dan Perizinannya, Yogyakarta: Legality, p. 2

${ }^{6}$ Muhammad Bakri, 2007, Hak Menguasai Tanah Oleh Negara (Paradigma Baru Untuk Reformasi Agraria), Yogyakarta: Citra Media, p. 5

${ }^{7}$ Soedharyo Soimin 2004, Status Hak dan Pembebasan Tanah, cet. 1, Jakarta: Sinar Grafika, p. 94

${ }^{8}$ Ibid, p. 95

${ }^{9}$ Article 1 (4) of Government Regulation No. 24 of 2016 regarding Amendment to Government Regulation No. 37 of 1998 on Land Deed Officer.

${ }^{10}$ Ibid, p. 79
} 
Volume 6 Issue 4, December 2019

Nationally Accredited Journal,

Decree No. B/4130/E5/E5.2.1/2019

Transitional Registration of Land and Property Rights or the Sale and Purchase Agreements Building Land Office Samarinda".

This study sought to answer concerns regarding the implementation of transitional registration of rights to land and buildings to the Sale and Purchase Agreements in Samarinda City Land Office as well as obstacles and solutions in the implementation of transitional registration of rights to land and or building with the Sale and Purchase Agreements in the Land Office Samarinda.

The purpose of this study was to: 1) analyze the implementation of transitional registration of rights to land and or building with the Sale and Purchase Agreements in the Land Office Samarinda. 2) Analyze the obstacles in the implementation of transitional registration of rights to land and or building with the Sale and Purchase Agreements in the Land Office Samarinda. 3) Know and analyze the solutions to overcome obstacles in the implementation of transitional registration of rights to land and or building with the Sale and Purchase Agreements in the Land Office Samarinda

\section{Research methods}

This type of research is normative. Normative research is a research method that refers to the legal norms contained in the legislation. This study also used juridical empirical approach, the research emphasizes the behavior of individuals or communities in connection with the law. ${ }^{11}$ Examining the effectiveness of a Law and Research wants to find a relationship (correlation) between a variety of symptoms, or variable as a means of collecting data consists of the study of documents, observation and interview. ${ }^{12}$

\section{Results and Discussion}

\subsection{Registration Implementation of Transfer of Rights on Land and Building with Sale and Purchase Agreements in the Land Office of Samarinda}

PPAT deed to be attended by the parties concerned to take legal actions (seller and buyer) or a person authorized by him with a written power of attorney in accordance with the legislation in force. The power of attorney for the seller to be with notarization, whereas the power of attorney for the buyer may by deed under hand. The documents submitted to the seller of PPAT in making the deed of sale is a photocopy of identity card (ID), a photocopy of the family, a marriage certificate, a tax return payable (SPPT) property tax. The documents submitted to the PPAT buyers in making the deed of sale is a photocopy of identity card (ID), a photocopy of the family, the marriage certificate.

Deed PPAT must be witnessed by at least two witnesses, according to the legislation in force qualified to act as a witness in a legal act, testifying among others, the presence of the parties or their attorneys, the existence of the documents shown in deed, and has been the implementation of the legal acts by the parties concerned.

Land Deed Official shall read the deed of sale to the parties concerned (buyers and sellers) and provide an explanation regarding the content and purpose of the deed, the

11 Soerjono Soekanto and Sri Mamadji 2009, Penelitian Hukum Normatif: Suatu Tinjauan Singkat, Jakarta: RajaGrafindo Persada, H.1

${ }^{12}$ Amiruddin, 2012, Pengantar Metode Penelitian Hukum, Jakarta: Raja Grafindo Persada, p15 
procedure of transfer of registration rights. PPAT Deed is made by two original sheets, the sheets are stored in the office PPAT and one sheet was delivered to the head of the local land office for registration purposes, whereas the parties concerned (buyers and sellers) were given a copy. ${ }^{13}$

Registration of transfer of rights over land held in the Land Office of Samarinda, referring to article 23 paragraph (1) BAL stated that property rights as well as the transition, abolishment and assignment with these rights shall be registered according to the provisions of Article 19 of the BAL, transfer of property rights the land can be various forms, including one of which is by way of buying and selling, therefore, the transition of land titles for purchase shall be registered according to the provisions of Article 19 of the BAL. The registration of transfer of land rights by way of buying and selling in Samarinda City Land Office, the applicant does not come directly to the Land Office. However, the transitional registration rights represented by PPAT. This, because in addition to PPAT in charge of making the deed of sale of land, PPAT also in charge of registration of transfers of rights at the local office no later than 7 days from the signing of the deed of sale of the land rights. Before making the transition of ownership of the land by way of sale and purchase, PPAT concerned shall carry out checks on the authenticity of the certificate to the Land Office.

Land Deed Official shall submit PPAT deed and other documents necessary for the purposes of registration of transfer of rights over the land to the local land office, no later than seven working days from the signing of the deed in question. The documents submitted by PPAT to register the transfer of land or property rights to the apartment units to the local land office is:

- Letter of application for registration of transfer of rights signed by the assignee (buyer) or their proxies,

- Written authorization of the assignee (buyer) when applying for registration of transfer of rights not right receiver (buyer).

- PPAT deed of sale by which time a deed was served and that the area of work includes the lay of the land in question

- Proof of identity rights of the assignor (seller)

- Proof of identity of the party receiving the right (buyer)

- Native land certificates were transferred (bought and sold)

- Permit the transfer of rights when necessary

- Proof of payment of fees for acquisition of land and buildings (BPHTB), in which case these duties are owed, and

- Proof of payment of income tax (VAT), in which case the tax owed.

Land title certificates that have changed the name of the holder of the rights holder long as the seller becomes the new rights holders as a buyer by the head of the local land office, then the entry will be submitted to the registration of transfer of land by the buyer or his proxy.

According to the Basic Agrarian Law, enrollment is strong evidence of the validity of the sale and purchase performed mainly in relation to third parties acting in good faith. Administrative registration is open so that everyone is considered to know. ${ }^{14}$ Article 19 of the Basic Agrarian Law governing the registration of land.

\footnotetext{
13 HMT Sahat Sinaga, 2007, Jual beli Tanah Dan Pencatatan Peralihan Hak, Bekasi: Pustaka Sutera, p.36.

${ }^{14}$ AP Parlindungan, 1990, Pendaftaran Tanah di Indonesia, Molds II, Bandung: Mandar Maju, p.14.
} 
Volume 6 Issue 4, December 2019

Nationally Accredited Journal,

Decree No. B/4130/E5/E5.2.1/2019

As the implementation of Article 19 of the Basic Agrarian Law concerning land registration was issued Government Regulation No. 24 of 1997 on Land Registration. Registered means is recorded and published proof of their rights. Proof of the rights referred to land rights consisting of a copy of the book and a letter of land measuring bound together in one envelope. The certificate is an evidentiary tool, meaning that the data contained therein have the force of law and must be accepted as correct information, and as long as no other means of proof to the contrary.

\subsection{Obstacles and Solutions in the Implementation of Transitional Registration of Rights to Land and or Building with the Sale and Purchase Agreements in the Land Office of Samarinda}

To be able to buy land on ownership status, it is not all buyers can buy land with the status of property rights, such as limited company, limited partnership may not buy or own, as well as foreign nationals (foreigners). Another limitation of authority of the deed of sale of land should not be made by PPAT were not working area. Incautiousness purchase of land without going through the PPAT will cause losses on the extent of land he bought. Often the land purchase made by witnesses and letters of purchase made by the village head. Widely used a number that may very well have come from petuk or other certificates that are not based on measurements and calculations kadastal. Therefore, the time will be certified, the land was measured, calculated and drawn, and then calculated acreage. Agreements that limit the location of which is measured by BPN and evidenced by the buyer's signature and adjacent landowners. In a purchase transaction, not a few cases that arise, such as the transfer of the land rights are forged the signatures of the seller's wife, as if the wife gives consent. ${ }^{15}$

The factors that affect the process of transition of property rights through the sale and purchase are:

- Or the negative factors that slow the process of transition of land rights, among others:

- Indifference parties buying and selling against all the rules that bind PPAT. Applicant came to PPAT with the hope that the problem can be solved quickly and well as possible regardless of whether it is the rules or regulations.

- Ignorance of the parties with respect to the existing requirements. One of the conditions for buying and selling land is to submit proof of payment of property tax last. In general, the parties to implement the transfer of land rights do not understand these terms so as not accompany the sale and purchase of land.

- Positive factors that can help the transition process of land rights, among others:

- The arrival of the parties to a transition of land rights can expedite the process of transition of land rights.

- With the information from PPAT the parties to a land rights switchover DAPT know the conditions to make the transition of land rights.

- Unfulfilled these conditions can accelerate the process of transition of land rights.

${ }^{15}$ Irawan Soerodjo, Kepastian Hukum Hak Atas Tanah di Indonesia, First Edition, Surabaya: Arkola, 2003, p.191. 
- The service of a fast and simple deed, until the deed transfer is registered and the name of the assignee, and will indirectly help the government in efforts to achieve the welfare of society.

- Cheapening the cost of the transition process to facilitate the land rights of the parties to implement the transition of land rights

The process of transfer of rights to land through purchase in the Land Office of Samarinda is a service registration transfer of land rights in accordance with Government Regulation No. 24 of 1997, has been set up and has been named agency or official, who was given the task and authority in the implementation of the service registration transfer of land rights. Similarly been arranged in ways that must be taken for each applicant as well as the requirements for obtaining a land title has. But in reality there are still many obstacles that occur, among others:

- Barriers arising from society.

- Still many low education level, resulting in a lack of public awareness, where people assume that by having the certificate on behalf of another person (the seller), the owner of the land has been acquiring rights to land and guarantee legal certainty.

- People feel reluctant to take care of their land rights switchover due to the costs which they say is quite high and will only confiscate their time.

- Barriers arising from the Land Office

- Lack of counseling given to the public about the importance of transitional registration of land rights for the sale and purchase, and the certification of the land.

- Lack of storage of documents, so many documents irregular and sometimes until the missing documents.

Steps Land Office Samarinda in overcoming barriers to the transition process of land rights through sale and purchase:

- Steps in overcoming the barriers caused by the public, among other things:

- Provide or publish brochures on the importance of transitional registration of land rights for the sale and purchase. This step is done by giving flyers to the public and put the flyer on the bulletin board at the office of the chief.

- Land Office in cooperation with the village chief to conduct counseling on land issues in an effort to raise awareness about the importance of communities to take the certificate.

- Steps in overcoming the barriers caused by the Land Office, among others:

- By improving the performance of the Land Office of Samarinda, fixing apparatus of the officers that are dealing with transitional registration and certification of land rights, through courses / training.

- Land Office Samarinda administration trying to fix because as the organization of human resources.

\section{Closing}

\subsection{Conclusion}

Based on the description above, the conclusions of this research are:

- Implementation of the transition of land rights begins with making the land deed and before PPAT, then by PPAT taken to the Land Office Samarinda to be listed as a certificate of property rights for rights holders on the new ground by bringing the necessary requirements. As these requirements are: 
Volume 6 Issue 4, December 2019

Nationally Accredited Journal,

Decree No. B/4130/E5/E5.2.1/2019

- Letter of application for registration of transfer of rights signed by the assignee (buyer) or their proxies,

- Written authorization of the assignee (buyer) when applying for registration of transfer of rights not right receiver (buyer).

- PPAT deed of sale by which time a deed was served and that the area of work includes the lay of the land in question

- Proof of identity rights of the assignor (seller)

- Proof of identity of the party receiving the right (buyer)

- Native land certificates were transferred (bought and sold)

- Permit the transfer of rights when necessary

- Proof of payment of fees for acquisition of land and buildings (BPHTB), in which case these duties are owed, and

- Proof of payment of income tax (VAT), in which case the tax owed.

- Barriers that occur in the process of transfer of rights to land through purchase in the Land Office of Samarinda is because people are reluctant to take care of their land rights switchover due to their cost, according them high enough and only seize their working time. The steps of the Land Office in overcoming these obstacles, whether they are due to society and caused by the Land Office is the Land Office in cooperation with the village chief to conduct counseling on the land issue as an attempt to raise public awareness about the importance of the certificate.

\subsection{Suggestion}

- Suggestions for Land Office Samarinda:

- Installing the application for transitional flow chart of land rights in place that is easily read by the public.

- Placing brochures at each booth, so that people who come to pick up and read it, so that the public can obtain information from the brochure.

- Conducting outreach to the community, in this case the Land Office Samarinda can approach them directly. With the direct approach, the public will better understand the possible registration of land especially transitional registration of rights to land through purchase, so that people can help smooth the transition process of registration of land rights.

- Suggestions for society

- For people who will make the transition treaty rights to land, let know about the requirements that will be needed in order to expedite the process of transition of land rights will be made by PPAT.

- For the people in doing the maintenance of the certificate should be done alone, so that is not exposed to illegal levies are mostly done by the brokers at the Land Office, so the cost is not too much.

- For the people whose land has not registered and do not have a certificate, in order to register their land to the local Land Office. This must be done to avoid the occurrence of land disputes in the future.

\section{References}

[1] AP Parlindungan, 1990, Pendaftaran Tanah di Indonesia, Molds II, Bandung: Mandar Maju 


\section{JURNAL AKTA}

[2] Amiruddin, 2012, Pengantar Metode Penelitian Hukum, Jakarta: Raja Grafindo Persada

[3] Dyara Radhite Oryza Fea, 2018, Panduan Mengurus Tanah Rumah dan Perizinannya, Yogyakarta: Legality

[4] Irawan Soerodjo 2003, Keapastian Hukum Hak Atas Tanah di Indonesia, First Edition, Surabaya: Arkola

[5] Muhammad Bakri, 2007, Hak Menguasai Tanah Oleh Negara (Paradigma Baru Untuk Reformasi Agraria), Yogyakarta: Citra Media

[6] Government Regulation No. 24 of 2016 regarding Amendment to Government Regulation No. 37 of 1998 on Land Deed Officer.

[7] HMT Sahat Sinaga, 2007, Jual beli Tanah Dan Pencatatan Peralihan Hak, Bekasi: Pustaka Sutera

[8] Soedharyo Soimin 2004, Status Hak dan Pembebasan Tanah, cet. 1, Jakarta: Sinar Grafika

[9] Soerjono Soekanto and Sri Mamadji 2009, Penelitian Hukum Normatif: Suatu Tinjauan Singkat, Jakarta: RajaGrafindo Persada

[10] Law of the Republic of Indonesia Number 5 of 1960 Agrarian Conditions. 